\section{Compatibility of Three Miticides with the Predatory Mites Neoseiulus californicus McGregor and Phytoseiulus persimilis Athias-Henriot (Acari: Phytoseiidae)}

\author{
Raymond A. Cloyd ${ }^{1}$ \\ Department of Natural Resources and Environmental Sciences, University of \\ Illinois, Urbana, IL 61801
}

\author{
Cindy L. Galle and Stephen R. Keith ${ }^{2}$ \\ AllTech Research and Development, Sparta, IL 62286
}

Additional index words. integrated pest management, lethal effects, survival, pesticides, natural enemies

\begin{abstract}
In this study, we report on the compatibility of two commercially available predatory mites, Neoseiulus californicus and Phytoseiulus persimilis, with three miticides used in greenhouse production systems to control the twospotted spider mite, Tetranychus urticae. We determined the lethal effects of the miticides chlorfenapyr, spiromesifen, and bifenazate to both predatory mite species 24 hours after exposure to spray applications in petri dishes. Two rates of chlorfenapyr $(0.40$ and $0.81 \mathrm{~mL} / 2-\mathrm{L})$ and spiromesifen $(0.15$ and $\left.0.31 \mathrm{~mL} \cdot \mathrm{L}^{-1}\right)$, and one rate of bifenazate $\left(0.62 \mathrm{~mL} \cdot \mathrm{L}^{-1}\right)$ were used. All rates were based on the manufacturer label recommendations for twospotted spider mite. Both rates of chlorfenapyr and spiromesifen, and the single rate of bifenazate were not harmful to $N$. californicus with percent live mite values $\geq \mathbf{8 5} \%$ for chlorfenapyr and $\geq \mathbf{9 5} \%$ for spiromesifen, and $93 \%$ for bifenazate. However, these same miticides were substantially toxic to $P$. persimilis with percent live mite values of $\leq 63 \%$ for all the miticides tested. Based on the results of this study, the miticides chlorfenapyr, spiromesifen, and bifenazate are compatible with $N$. californicus whereas these miticides are toxic to $P$. persimilis indicating a difference in susceptibility based on predatory mite species.
\end{abstract}

Twospotted spider mite, Tetranychus urticae Koch (Acari: Tetranychidae) is a major arthropod pest in greenhouses, particularly during the warm season when populations can reach excessive levels within a short period of time (Helle and Sabelis, 1985; Zhang, 2003). Commercially available miticides are typically used to control twospotted spider mite outbreaks. However, continued reliance on miticides increases the probability of $T$. urticae populations developing resistance (Dittrich, 1975; Carbonaro et al., 1986). As a result, greenhouse producers are evaluating the use of alternative management strategies for twospotted spider mite that may avoid relying strictly on miticides (Sabelis, 1981).

An alternative management strategy, as opposed to relying solely on miticides, is to incorporate the use of predatory mites into greenhouse production systems. Two predatory mites that are available to greenhouse producers are Phytoseiulus persimilis AthiasHenriot (Acari: Phytoseiidae) and Neoseiulus

\footnotetext{
Received for publication 4 Nov. 2005. Accepted for publication 23 Jan. 2006. We thank JP Macke for providing technical support. We also wish to acknowledge OHP, Inc., Mainland, Pa., for providing funding for this research.

${ }^{1}$ Associate professor, To whom correspondence should be addressed; e-mail rcloyd@uiuc.edu.

${ }^{2}$ Research technician and owner, Current address; AllTech Research and Development, Sparta, Ill.
}

californicus McGregor (Acari: Phytoseiidae). Predatory mites in the family Phytoseiidae have been successful in controlling twospotted spider mites in interior plantscapes (Hamlen, 1978; Helle and Sabelis, 1985; McMurtry, 1982). Phytoseiulus persimilis has been widely used to control twospotted spider mites on greenhouse-grown crops including roses (Burgess, 1984; Casey and Parrella, 2002; Simmonds, 1972), and foliage plants (Hamlen and Lindquist, 1981). Phytoseiulus persimilis is considered a type I (specialized) predator because it only feeds and is able to survive on T. urticae (McMurtry and Croft, 1997). In addition, $P$. persimilis requires a specific temperature $\left(27^{\circ} \mathrm{C}\right)$ and relative humidity range (60\% to $80 \%$ ) for population growth (Stenseth, 1979). In contrast, Neoseiulus californicus is a type II (selective) predator because it feeds and can survive on alternative prey and pollen in the absence of T. urticae (McMurtry and Croft, 1997). This predatory mite also tolerates a lower relative humidity than $P$. persimilis (Scopes, 1985; Palevsky et al., 1999; Zhang, 2003). Despite previous success using these predatory mites and their availability, the sole use of phytoseiid mites may not provide sufficient control of twospotted spider mite populations (Burnett, 1979; Field and Hoy, 1986; Helle and Sabelis, 1985; Zhi-Qiang and Sanderson, 1990). As such, combining the use of miticides with predatory mites may be an amenable management strategy that can reduce miticide use, thus limiting the potential for resistance. For example, miticides can be used to reduce high mite populations as long as they don't disrupt the ability of the predatory mites to maintain mite numbers below damaging levels.

Several miticides have been recently introduced for control of twospotted spider mites in greenhouses; these include chlorfenapyr (Pylon; OHP, Mainland, Pa.), spiromesifen (Judo; OHP, Mainland, Pa.), and bifenazate (Floramite; Chemtura, Middlebury, Conn.). Chlorfenapyr is a contact and stomach poison insecticide-miticide in the pyrazole group. This insecticide-miticide also has translaminar properties, which means that it penetrates the leaf cuticle and forms a reservoir of active ingredient within the leaf. Chlorfenapyr works by uncoupling oxidative phosphorylation, which disrupts the $\mathrm{H}^{+}$gradient and prevents the formation of adenosine tri-phosphate or ATP (Thomson, 2001; Ware and Whitacre, 2004). Spiromesifen is an insecticide-miticide in the tetronic acid group with both contact and translaminar attributes. Spiromesifen has one of the newest modes of action. This insecticide-miticide blocks the production of lipids, which disrupts cell membranes and reduces energy synthesis (Thomson, 2001; Ware and Whitacre, 2004). Bifenazate is a contact miticide with a hydrazinobiphenyl structure. Bifenazate kills mites by blocking gammaamino butyric acid-activated chloride channels in the peripheral nervous system (Thomson, 2001; Ware and Whitacre, 2004).

These relatively new miticides have not been thoroughly evaluated to assess whether they are compatible with commercially available biological control agents including predatory mites at rates labeled for twospotted spider mite. As such, the purpose of this study was to determine the immediate (or short-term) lethality of three miticides on the predatory mites Neoseiulus californicus and Phytoseiulus persimilis under laboratory conditions.

\section{Materials and Methods}

Two experiments were conducted in a laboratory to assess the lethal effects of several miticides on the predatory mites, Neoseiulus californicus and Phytoseiulus persimilis.

Experiment 1. Effects of the miticide chlorfenapyr on the predatory mites, Neoseiulus californicus and Phytoseiulus persimilis. Forty petri dishes $(100 \times 15 \mathrm{~mm})$ were prepared with a moistened filter paper (No. 1, Whatman, 90 $\mathrm{mm}$ ) and a mature soybean, Glycine $\max (\mathrm{L}$. Merrill leaf for the first trial of this experiment or a segment $(6.5 \times 4.5 \mathrm{~cm})$ of a Transvaal daisy, Gerbera jamesonii (H. Bolus ex Hook f) leaf for the second trial of the experiment. Predatory mites used in this experiment were obtained from IPM Laboratories, Inc. (Locke, N.Y.). When the predatory mites arrived from the supplier they were processed immediately. Prior to use in the experiment, the containers were visually evaluated to ensure that the predatory mites were alive and moving around. The containers were carefully shaken, for 
$5 \mathrm{~s}$, to evenly distribute the predatory mites throughout the container. Then, about $0.25 \mathrm{~g}$ of packing substance containing $N$. californicus and $4.02 \mathrm{~g}$ of packing substance containing $P$. persimilis (in the second trial of the experiment, $0.25 \mathrm{~g}$ of packing substance was used) were measured and placed into each designated petri dish. There were about 18 predatory mites per petri dish for each trial. One petri dish was equivalent to one replicate. Treatments were applied by placing the measured amount of each miticide into a 2-L bottle containing deionized water, mixing the solution, and then pouring this solution into a $100 \mathrm{~mL}$ glass beaker where a spray nozzle from a $946 \mathrm{~mL}$ spray bottle was inserted. Each designated petri dish received one full spray $(2.0 \mathrm{~mL})$ for all the treatments, which was enough volume to thoroughly cover the leaf in the petri dish. After application, each soybean and Transvaal daisy leaf was infested with 10 to 15 twospotted spider mite (Tetranychus urticae) adults and nymphs obtained from a colony reared on soybean plants at $30 \pm 3{ }^{\circ} \mathrm{C}, 60 \%$ to $90 \%$ relative humidity, and 12:12(L:D) hour photoperiod. These mites were provided as a food source for the predator mites. In the second trial of the experiment, twospotted spider mites were added as needed to the petri dishes within the 5-d trial period. Each petri dish was sealed with tape (NexCare 3M Micropore Surgical Tape; 3M Consumer Health Care, St. Louis, Mo.). The petri dishes were arranged in a completely randomized design in a laboratory with a 9:15 (L:D) hour photoperiod. Twenty-four hours following application, for the first trial of the experiment, each soybean leaf was processed to assess the number of live, dead, and total number of each predatory mite species. In the second trial of the experiment, five days following application, each Transvaal daisy leaf was processed to determine the number of live, dead, and total number of $P$. persimilis. Phytoseiulus persimilis was the only predatory mite tested in the second trial because it is the most widely used predatory mite in greenhouses. There were four treatments with 10 replications per predatory mite species per treatment in the first trial. Similarly, there were four treatments with 10 replications per treatment for $P$. persimilis in the second trial. The treatments were chlorfenapyr (Pylon SC; OHP, Mainland, $\mathrm{Pa}$.) at $2.6 \mathrm{fl} \mathrm{oz} / 100$ gallons $(0.40 \mathrm{~mL} / 2-\mathrm{L})$, chlorfenapyr (Pylon SC) at $5.2 \mathrm{fl} \mathrm{oz} / 100$ gallons $(0.81 \mathrm{~mL} / 2-\mathrm{L})$, a water control, and an untreated check. The chlorfenapyr rates used were the low and high-labeled recommended rates for twospotted spider mite.

Data were evaluated using SAS Systems for Windows, version 8.2. Percent live predatory mites were determined by dividing the number of live predatory mites by the total number of predatory mites per petri dish. These values were normalized by arcsine square root transformation and subjected to a one-way analysis of variance (ANOVA) (SAS Institute, 2002) with treatment as the main effect. Significant treatment means were separated using a Fisher's protected least significant difference test at $P \leq 0.05$. All data presented are nontransformed.
Experiment 2. Effect of the miticides spiromesifen and bifenazate on the predatory mites, Neoseiulus californicus and Phytoseisterile petri dishes $(100 \times 15 \mathrm{~mm})$ were prepared with moistened filter paper (No. 1, Whatman, $90 \mathrm{~mm}$ ) and a cotton (Gossypium sp.) leaf. One set of 40 was for $N$. californicus and the other set for $P$. persimilis. One petri dish was equivalent to one replicate for each predatory mite species. The predatory mites used in this experiment were also obtained from IPM Laboratories, Inc. (Locke, N.Y.). When the predatory mites arrived from the supplier they were processed immediately. As in the first experiment, the containers were visually evaluated to ensure that predatory mites were alive and moving around. The containers were carefully shaken, for $5 \mathrm{~s}$, to evenly distribute the predatory mites throughout the container. Then, about $0.25 \mathrm{~g}$ of packing substance containing $N$. californicus and $0.30 \mathrm{~g}$ of packing substance containing $P$. persimilis was measured and placed into each designated petri dish. There were 1 to $3 N$. californicus mites per petri dish, and 1 to $5 P$. persimilis mites per petri dish. Treatments were applied by placing the measured amount of each miticide into a $1-\mathrm{L}$ bottle containing deionized water, mixing the solution, and then pouring this solution into a $100 \mathrm{~mL}$ glass beaker where a nozzle from a $946 \mathrm{~mL}$ spray bottle was inserted. Each designated petri dish received one full spray (2.0 $\mathrm{mL}$ ) of solution for all the treatments, which was a sufficient volume to thoroughly cover the cotton leaf. After application, the cotton leaf was infested with 10 twospotted spider mite ( $T$. urticae) adults and nymphs obtained from the colony described in experiment one, which provided a food source for the predator mites. Each petri dish was then sealed with tape (NexCare 3M Micropore Surgical Tape; $3 \mathrm{M}$ Consumer Health Care, St. Louis, Mo.). The petri dishes were arranged in a completely ulus persimilis. Two sets of 40 Nunc Lab-Tek

randomized design in a laboratory with a 9:15 (L:D) hour photoperiod. Twenty-four hours following application, the numbers of live, dead, and total number of each predatory mite species was determined. There were a total of four treatments with 10 replications per treatment for each predatory mite species. The treatments were spiromesifen (Judo SC; OHP, Mainland, $\mathrm{Pa}$.) at $2.0 \mathrm{fl} \mathrm{oz} / 100$ gallons $\left(0.15 \mathrm{~mL} \cdot \mathrm{L}^{-1}\right)$, spiromesifen (Judo SC) at 4.0 fl oz/100 gallons $\left(0.31 \mathrm{~mL} \cdot \mathrm{L}^{-1}\right)$, bifenazate (Floramite SC; Chemtura, Middlebury, Conn.) at $8.0 \mathrm{fl} \mathrm{oz} / 100$ gallons $\left(0.62 \mathrm{~mL} \cdot \mathrm{L}^{-1}\right)$, and an untreated check. There was no water control in this experiment, as it was not requested in the initial protocol. The rates for spiromesifen were the low and high-labeled recommended rates for twospotted spider mite, and the bifenazate rate used was the highest recommended label rate for twospotted spider mite. The procedures for data analysis and obtaining percent live mite values were the same as in first experiment.

\section{Results}

Experiment 1. Effects of the miticide chlorfenapyr on the predatory mites, Neoseiulus californicus and Phytoseiulus persimilis. There were no significant differences among the treatments regarding percent live $N$. californicus $(\mathrm{F}=0.44 ; \mathrm{df}=3,39 ; P=0.72)$ (Table 1 ) with percent live mite values $\geq 85 \%$ for both rates of chlorfenapyr. The treatments were significant in regards to percent live $P$. persimilis $(\mathrm{F}=38.29 ; \mathrm{df}=3,39 ; P<0.0001)$ with both rates of chlorfenapyr having significantly lower percent live predatory mites ( $47 \%$ and $52 \%$, respectively) than the water control and untreated check (Table 1). For the second trial of the experiment, there were no significant differences among the treatments in percent live $P$. persimilis $(\mathrm{F}=0.61 ; \mathrm{df}=3$, 39; $P=0.61$ ) (Table 1).

Table 1. Percent live Neoseiulus californicus McGregor and Phytoseiulus persimilis Athias-Henriot $1 \mathrm{~d}$ after treatment (DAT) for the first trial in experiment one, and percent live Phytoseiulus persimilis AthiasHenriot $5 \mathrm{~d}$ after treatment (DAT) for the second trial in experiment one for all treatments. There were about 18 predatory mites per petri dish for each trial.

\begin{tabular}{|c|c|c|c|c|c|}
\hline \multirow[b]{2}{*}{ Treatment } & \multirow[b]{2}{*}{$\mathrm{n}$} & \multirow[b]{2}{*}{ Rate } & \multicolumn{2}{|c|}{ First trial } & \multirow{2}{*}{$\begin{array}{c}\text { Second trial } \\
\text { Phytoseiulus } \\
\text { persimilis } \\
5 \text { DAT }\end{array}$} \\
\hline & & & $\begin{array}{c}\text { Neoseiulus } \\
\text { californicus } \\
1 \text { DAT }\end{array}$ & $\begin{array}{c}\text { Phytoseiulus } \\
\text { persimilis } \\
\text { 1 DAT }\end{array}$ & \\
\hline Chlorfenapyr & 10 & $0.40 \mathrm{~mL} / 2 \mathrm{~L}$ & $89 a^{z}$ & $47 \mathrm{c}$ & $31 \mathrm{a}$ \\
\hline Chlorfenapyr & 10 & $0.81 \mathrm{~mL} / 2 \mathrm{~L}$ & $85 \mathrm{a}$ & $52 \mathrm{c}$ & $32 \mathrm{a}$ \\
\hline Water control & 10 & --- & $80 \mathrm{a}$ & $86 \mathrm{~b}$ & $30 \mathrm{a}$ \\
\hline Untreated check & 10 & --- & $88 \mathrm{a}$ & $93 \mathrm{a}$ & $34 \mathrm{a}$ \\
\hline
\end{tabular}

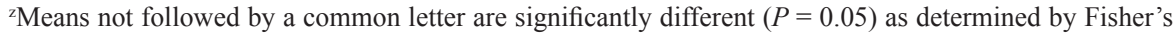
protected least significant difference (LSD) test.

Table 2. Percent live Neoseiulus californicus McGregor and Phytoseiulus persimilis Athias-Henriot $1 \mathrm{~d}$ after treatment (DAT) for all treatments in experiment two. Numbers in parentheses indicate the total number of predatory mites per treatment.

\begin{tabular}{lcccc}
\hline & & & Neoseiulus californicus & Phytoseiulus persimilis \\
Treatment & $\mathrm{n}$ & Rate & $1 \mathrm{DAT}$ & 1 DAT \\
\hline Spiromesifen & 10 & $0.15 \mathrm{~mL} \cdot \mathrm{L}^{-1}$ & $100 \mathrm{a}^{\mathrm{z}}(17)$ & $44 \mathrm{a}(21)$ \\
Spiromesifen & 10 & $0.31 \mathrm{~mL} \cdot \mathrm{L}^{-1}$ & $95 \mathrm{a}(19)$ & $63 \mathrm{ab}(27)$ \\
Bifenazate & 10 & $0.62 \mathrm{~mL} \cdot \mathrm{L}^{-1}$ & $93 \mathrm{a}(15)$ & $33 \mathrm{a}(10)$ \\
Untreated check & 10 & --- & $100 \mathrm{a}(16)$ & $87 \mathrm{~b}(27)$ \\
\hline
\end{tabular}

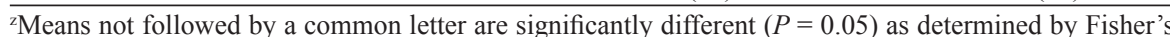
protected least significant difference (LSD) test. 
Experiment 2. Effect of the miticides spiromesifen and bifenazate on the predatory mites, Neoseiulus californicus and Phytoseiulus persimilis. There were no significant differences among the treatments for percent live $N$. californicus $(\mathrm{F}=0.74 ; \mathrm{df}=3,34 ; P=$ $0.53)$. In fact, the percent live predatory mites (based on the total number recovered) ranged from $93 \%$ to $100 \%$ for the miticide treatments (Table 2). The treatments were significant regarding percent live $P$. persimilis $(\mathrm{F}=3.29$; $\mathrm{df}=3,34 ; P=0.033)$ with the high rate of spiromesifen $\left(0.31 \mathrm{~mL} \cdot \mathrm{L}^{-1}\right)$ not significantly different from the untreated check whereas both the low rate of spiromesifen $\left(0.15 \mathrm{~mL} \cdot \mathrm{L}^{-1}\right)$ and highest label rate of bifenazate $\left(0.62 \mathrm{~mL} \cdot \mathrm{L}^{-1}\right)$ had significantly lower percent live $P$. persimilis than the untreated check (Table 2). The percent live $P$. persimilis for the miticides tested were $\leq 63 \%$, which was substantially lower than the percent live mite values for $N$. californicus (Table 2).

\section{Discussion}

In this study, there were differences in susceptibility of the predatory mites to the various miticides with the high and low labeled rates of both spiromesifen and chlorfenapyr, and the high labeled rate of bifenazate more acutely toxic to the predatory mite, $P$. persimilis, based on percent live predatory mites, than N. californicus. This difference in susceptibility to the miticides tested may be due to the physiological characteristics and/or foraging behavior of each predatory mite species. In addition, it has been suggested that these different responses may be due to $P$. persimilis strains having distinctive degrees of susceptibility to miticides or any variability in the composition of the miticide formulation (Blumel and Gross, 2001) including the percentage of active and inert ingredients. Differential toxicities to miticides have been demonstrated with abamectin and the predatory mite, Metaseiulus occidentalis (Nesbitt) (Acari: Tetranychidae) (Grafton-Cardwell and Hoy, 1983).

Studies have been conducted to determine the lethal effects of pesticides, used in greenhouses to control twospotted spider mite, on P. persimilis, more so than on N. californicus. For example, Blumel and Gross (2001) demonstrated that the miticide hexythiazox was not harmful to $P$. persimilis under laboratory conditions. It has also been determined that azadirachtin, a neem-based insecticide-miticide does not negatively affect female $P$. persimilis fecundity (Spollen and Isman, 1996). Zhi-Qiang and Sanderson (1990) reported that abamectin, at low concentrations, does not negatively affect the survival and mobility of $P$. persimilis. This was based on bean (Phaseolus vulgaris L.) leaf disks containing mites directly submerged in various concentrations of abamectin. However, using slide-dip tests, potassium salts of fatty acids or insecticidal soap resulted in $>95 \%$ mortality of $P$. persimilis adults (Osborne and Petitt, 1985). Additionally, the entomopathogenic fungus, Beauveria bassiana has been shown to be toxic to P. persimilis (Ludwig and Oetting,
2001). This same fungus as well as rotenone, a botanically based insecticide-miticide, which is not labeled for use in greenhouses, significantly reduced fecundity and survival of $N$. californicus under laboratory conditions (Castagnoli et al., 2005).

Both chlorfenapyr and spiromesifen are comparatively newer introductions than bifenazate, so relatively little is known regarding the compatibility of these miticides with predatory mites. However, Cote et al. (2002) tested the lethal effects of a number of miticides on P. persimilis and found that chlorfenapyr was most harmful to this predatory mite, even 14 days after treatment, at $0.81 \mathrm{~mL} \cdot \mathrm{L}^{-1}$, which is the high label rate. This is consistent with our study; however, we also found that the low label rate $\left(0.40 \mathrm{~mL} \cdot \mathrm{L}^{-1}\right)$ was detrimental to $P$. persimilis based on percent live predatory mites (Table 1). Chlorfenapyr has also been shown to be highly toxic to the predatory mite, Agistemus industani Gonzalez (Acari: Stigmaeidae) (Childers et al., 2001). In contrast, we found that chlorfenapyr and spiromesifen were not harmful to $N$. californicus at both the low and high label rates with percent live predatory mite values of $85 \%$ and $89 \%$ for chlorfenapyr, and $95 \%$ and $100 \%$ for spiromesifen. In addition, bifenazate appeared to be nontoxic to $N$. californicus even at the highest label rate with a percent live predatory mite value $>90 \%$. Bifenazate, at one-half and three-quarter rates, has also been shown to be compatible with a closely related predatory mite species, $N$. fallacis Garman based on laboratory bioassays (James, 2002).

During the second trial of the first experiment, we experienced problems related to quality control in that of high mortality of $P$. persimilis (about $80 \%$ ), which was based on visual assessments prior to use. This may have been the result of inadequate shipping or storage conditions, or problems related with the main colony at the supplier (McClanahan, 1968). Phytoseiulus persimilis packed for shipping in granular carriers is susceptible to delays during handling, which results in mortality from cannibalism or desiccation. For example, $P$. persimilis shipped without prey will start feeding on any eggs and nymphs (Markkula et al., 1987). In fact, we had to request three additional shipments from the distributor (from different suppliers) to conduct this part of the experiment. The circumstances of quality associated with $P$. persimilis are reflected in the results with the low percent live mite values $(\leq 34 \%)$ for all treatments (Table 1). Despite this, the fact that both rates of chlorfenapyr were not significantly different from the water control and untreated check suggests that the miticide was not chronically toxic to $P$. persimilis. We decided to include these data to demonstrate the importance of quality control when using biological control agents.

In our study, the miticides chlorfenapyr, spiromesifen, and bifenazate were not directly harmful to $N$. californicus whereas these same miticides were toxic to $P$. persimilis. We did not evaluate the sub-lethal effects of the miticides, which may also affect the prospects of using these miticides with the predatory mites
(Oomen et al., 1991). Our study is the first to quantify the lethal effects of chlorfenapyr on $N$. californicus, and the lethal effects of spiromesifen on both $N$. californicus and P. persimilis under laboratory conditions. However, further research is still needed to quantify the sublethal effects of chlorfenapyr, spiromesifen, and bifenazate on the life history parameters of the predatory mites including fecundity, oviposition, and foraging behavior (not only in the laboratory but also under greenhouse conditions). It should be noted that the conditions of these experiments, in which petri dishes were sealed with tape to prevent any mites (both predatory and prey) from escaping, may have reduced the ability of the miticides to evaporate thus extending the exposure period of the predatory mites to any miticide residues. In addition, these conditions may have resulted in a higher relative humidity than would be experienced in a greenhouse. However, despite these conditions, $N$. californicus was still not harmed by any of the miticides tested in both experiments although these same conditions may have negatively affected $P$. persimilis. This study provides a starting point for evaluating the compatibility of the miticides tested with predator mites. However, further studies need to be conducted, particularly under greenhouse conditions, on the effect of dry residues on both predatory mite species. For example, Shipp et al. (2000) found that $P$. persimilis was less negatively affected, based on percent mortality, by $\geq 6$-d old residues of the miticides avermectin b1 and pyridaben. The results of our study are important to greenhouse producers that intend to use predatory mites along with supplemental applications of miticides to control twospotted spider mites without disrupting the long-term success of biological control programs.

\section{Literature Cited}

Blumel, S. and M. Gross. 2001. Effect of pesticide mixtures on the predatory mite Phytoseiulus persimilis A.H. (Acarina, Phytoseiidae) in the laboratory. J. Appl. Entomol. 125:201-205.

Burgess, E.L. 1984. Integrated control of two-spotted spider mite on glasshouse roses, p. 257-261. In: Proc. 37th New Zealand Weed and Pest Control Conf., Christchurch.

Burnett, T. 1979. An acarine predatory-prey population infesting roses. Res. Pop. Ecol. (Kyoto) 20:227-234.

Carbonaro, M.A., D.E. Moreland, V.E. Edge, N. Motoyama, G.C. Rock, and W.C. Dauterman. 1986. Studies on the mechanisms of cyhexatin resistance in the twospotted spider mite, Tetranychus urticae (Acari: Tetranychidae). J. Econ. Entomol. 79:576-579.

Casey, C. and M. Parrella. 2002. Demonstration and implementation of a reduced risk pest management strategy in fresh cut roses. Inter. Org. Biolog. Control/Western Palaearctic Reg. Section Bull. 25: 45-48.

Castagnoli, M., M. Liguori, S. Simoni, and C. Duso. 2005. Toxicity of some insecticides to Tetranychus urticae, Neoseiulus californicus and Tydeus californicus. BioControl 50:611-622.

Childers, C.C., R. Villanueva, H. Aguilar, R. Chewning, and J.P. Michaud. 2001. Comparative residual toxicities of pesticides to the predator Agistemus industani (Acari: Stigmaeidae) on citrus in Florida. Expt. Appl. Acarol. 25:461-474.

Cote, K.W., E.E. Lewis, and P.B. Schultz. 2002. 
Compatibility of acaricide residues with Phytoseiulus persimilis and their effects on Tetranychus urticae. HortScience 37(6):906-909.

Dittrich, V. 1975. Acaricide resistance in mites. Z. Angew. Entomol. 78:28-45.

Field, R.P., and M.A. Hoy. 1986. Evaluation of genetically improved strains of Metaseiulus occidentalis (Nesbitt) (Acarina: Phytoseiidae) for integrated control of spider mites on roses in greenhouses. Hilgardia 54:1-31.

Grafton-Cardwell, E.E. and M.A. Hoy. 1983. Comparative toxicity of avermectin B1 to the predator Metaseiulus occidentalis (Nesbitt) (Acari: Tetranychidae). J. Econ. Entomol. 76:1216-1220.

Hamlen, R. A. 1978. Biological control of spider mites on greenhouse ornamentals using predaceous mites. Proc. Fla. State Hort. Soc. 91:247-249.

Hamlen, R.A. and R.K. Lindquist. 1981. Comparison of two Phytoseiulus species as predators of twospotted spider mites on greenhouse ornamentals. Environ. Entomol. 10:524-527.

Helle, W. and M. W. Sabelis. 1985. Spider mites: Their biology, natural enemies and control. Volume 1B, Elsevier, Amsterdam.

James, D.G. 2002. Selectivity of the acaricide, bifenazate, and aphicide, pymetrozine, to spider mite predators in Washington hops. Intl. J.Acarol. 28(2):175-179.

Ludwig, S.W. and R.D. Oetting. 2001. Susceptibility of natural enemies to infection of Beauveria bassiana and impact of insecticides on Ipheseius degenerans (Acari: Phytoseiidae). J. Agr. Urban Entomol. 18(3):169-178.

Markkula, M., K. Tittanen, and H.M. T. Hokkanen. 1987. Failures of biological control of spider mites due to predatory mites or their users? Bull. Intl. Org. Biol. Integrated Control/West
Palaearctic Reg. Sect. 10(2):108-110.

McClanahan, R.J. 1968. Influence of temperature on the reproductive potential of two mite predators of the two-spotted spider mite. Can. Entomol. 100(5): 549-556.

McMurtry, J.A. 1982. The use of phytoseiid for biological control: progress and future prospects, p. 23-48. In: Recent advances in knowledge of Phytoseiidae. M.A. Hoy (ed.). Div. Agr. Sci. Calif. Publ. 3284. Ministerio de Agricultura, Pesca y Alimentacion, Madrid.

McMurtry, J.A. and B.A. Croft. 1997. Life-styles of phytoseiid mites and their roles in biological control. Annu. Rev. Entomol. 42:291-321.

Oomen, P.A., G. Romeijn, and G.L. Wiegers. 1991. Side-effects of 100 acaricides on the predatory mite Phytoseiulus persimilis, collected and evaluated according to the EPPO guideline. Bul. Euro. Mediterranean Plant Protection Org. (OEPP/EPPO) 21:701-712.

Osborne, L.S. and F.L. Petitt. 1985. Insecticidal soap and the predatory mite, Phytoseiulus persimilis (Acari: Phytoseiidae), used in management of the twospotted spider mite (Acari: Tetranychidae) on greenhouse grown foliage plants. J. Econ. Entomol. 78:687-691.

Palevsky, E., H. Reuveny, O. Okonis, and U. Gerson. 1999. Comparative behavioural studies of larval and adult stages of the phytoseiids (Acari: Mesostigmata) Typhlodromus athiasae and Neoseiulus californicus. Expt.Appl. Acarol. 23:467-485.

Sabelis, M. W. 1981. Biological control of two-spotted spider mites using phtyoseiid predators. Part 1. Modeling the predator-prey interaction at the individual level.Agr. Res. Rpt.910. Wageningen, The Netherlands.

SAS Institute. 2002. SAS/STAT users guide. v. 8.2. SAS Inst., Inc., Cary, N.C.
Shipp, J.L., K. Wang, and G. Ferguson. 2000. Residual toxicity of avermectin b1 and pyridaben to eight commercially produced beneficial arthropod species used for control of greenhouse pests. Biolog. Control 17:125-131.

Simmonds, S.P. 1972. Observations on the control of Tetranychus urticae on roses by Phytoseiulus persimilis. Plant Pathol. 21:163-165.

Scopes, N.E.A. 1985. Red spider mite and the predator Phytoseiulus persimilis, p. 43-52. In: N.W. Hussey and N. Scopes (eds.). Biological pest control: The glasshouse experience. Cornell Univ. Press, Ithaca, N.Y.

Spollen, K.M. and M.B. Isman. 1996. Acute and sublethal effects of neem insecticide on the commercial biological controls Phytoseiulus persimilis and Amblyseius cucumeris (Acari: Phytoseiidae) and Aphidoletes aphidimyza (Diptera: Cecidomyiidae). J. Econ. Entomol. 89(6):1379-1386.

Stenseth, C. 1979. Effect of temperature and humidity on the development of Phytoseiulus persimilis and its ability to regulate populations of Tetranychus urticae (Acarina: Phytoseiidae, Tetranychidae). Entomoph. 249:311-317.

Thomson, W.T. 2001. Agricultural chemicals book I: Insecticides, acaricides, and ovicides. Thomson Publications, Fresno, Calif.

Ware, G.W. and D.M. Whitacre. 2004. The pesticide book. 6th ed. MeisterPro Info. Resources, Willoughby, Ohio.

Zhang, Z-Q. 2003. Mites of greenhouses: Identification, biology, and control. CAB Intl. Publ., Wallingford, Oxon, U.K.

Zhi-Qiang, Z. and J.P. Sanderson. 1990. Relative toxicity of abamectin to the predatory mite Phytoseiulus persimilis (Acari: Phytoseiidae) and twospotted spider mite (Acari: Tetranychidae). J. Econ. Entomol. 83(5):1783-1790. 